\title{
LONG BEFORE AÏ-KHANOUM: HISTORIOGRAPHICAL REPRESENTATION OF HELLENISTIC BACTRIA IN BARTHOLD NIEBUR'S VÖRTRAGE ÜBER ALTE GESCHICHTE
}

\author{
Fábio Augusto Morales ${ }^{1}$ \\ Santiago Colombo Reghin ${ }^{2}$
}

\begin{abstract}
This paper deals with the historiographical representation of Hellenistic Bactria in Barthold Niebuhr's Lectures on Ancient History, based on lectures given at Bonn University in the 1820's and published in German and English in the 1850's. The first part offers a panorama of archaeological, epigraphic and numismatic research after the great French excavations in Afghanistan in the 1960 and 1970's. The second part discusses how Niebuhr, facing a poorly documented Bactrian history and archaeology, articulate source criticism, demographic, moral and racial reasoning and contemporary political debate. The paper concludes with a summary of the discussion, arguing for the necessity of historicization of historiographical syntheses as well in nineteenth century as today, especially in the context of Global History.
\end{abstract}

\section{Key-words}

German historicism; Hellenistic Bactria; Aï Khanoum; Niebuhr; Global History.

\footnotetext{
${ }^{1}$ Assistant Professor - Federal University of Santa Catarina, Florianópolis, Brazil.

E-mail: fabio.morales@ufsc.br

2 Graduate student in History - Federal University of Santa Catarina, Florianópolis, Brazil. E-mail: santiago_tj96@hotmail.com
}

Heródoto, Unifesp, Guarulhos, v.4, n.1 - 2019.1. p. 122-138

DOI: 10.34024/herodoto.2019.v4.10091 


\section{Resumo}

O presente artigo trata das representações historiográficas da Báctria helenística nas Lições de História Antiga de Barthold Niebuhr, ministradas na Universidade de Bonn na década de 1820 e publicadas em alemão e inglês na década de 1850. Após um panorama do quadro atual das pesquisas sobre a Báctria Helenística, revolucionado pelas escavações francesas nas décadas de 1960 e 1970, o artigo explora o modo como Niebuhr, diante de um então pouco documentado objeto histórico, articula crítica documental, raciocínio demográfico, moral e racial, e os debates políticos contemporâneos. O artigo conclui com uma síntese da discussão, defendendo a necessidade da historicização das sínteses historiográficas tanto do século XIX quanto as atuais, especialmente no contexto da História Global.

\section{Palavras-chave}

Historicismo alemão; Báctria helenística; Aï Khanoum; Niebuhr; História Global. 
From both global and local viewpoints, the history and archaeology of Hellenistic Bactria is one of the most interesting subjects for the history of Ancient globalizations. In the last decades striking documental corpora, produced after the French excavations in sites such as Aï Khanoum and Takht-i Sangin and surveys in extensive areas, were added to the previously sparse and fragmented available literary and numismatic sources. The growing number of studies dedicated to Hellenistic Bactria points to new perspectives both in the chronology and political history of Graeco-Bactrian kingdom and the analysis of economic, political and cultural aspects of interregional and multi-ethnic connections that have taken place there. In fact, the history and archaeology of Hellenistic Bactria can undoubtedly aspire centrality in a context of a growing dialogue between Ancient and Global History (Hodos, 2014; Vlassopoulos, 2016; Burstein, 2017; Knust, 2019; Scopacasa, 2018; Morales; Silva, 2019).

The topics debated by recent scholarship derive, however, more from the formation of Hellenistic Studies than from contemporary Global Studies. One of the main topics is the Hellenization process, understood either as the adoption of Greek cultural features by local, non-Greek communities or the collective construction of a Greek identity (Vlassopoulos, 2013). Since the middle of the nineteenth century scholars have sponsored opposite views, which have varied on the evaluation of its influence on non-Greek populations and the agency they have on the process itself. The aim of this paper is to analyze the treatment given to the 'Hellenization problem' by B. Niebuhr on his Vörtrage über alte Geschichte, taking his representation of Bactria as case study - long before the source revolution after the French excavations of the 1960 and 1970's. Founder of the Classicsbased modern Ancient History and the historical method of source criticism, Niebuhr dedicated his first course at Bonn University, in 1823, to 'die Spätere Griechisch Geschichte im Allgemeinen', comprising the period from the fourth to the first century B.C.; notes written by Niebuhr and his students of the course's 31 lessons were published in German in 1851 and in English the next year, as the third volume of his Vörtrage.

In fact, before the French excavations turned Hellenistic Bactria a recurrent theme in Hellenistic History introductions, it was only marginally treated in historiographical syntheses. Nevertheless, the historiographical representation of Bactria in those syntheses, such as Niebuhr's, reveals the main concepts and morphological solutions the authors were working with to solve some central issues. What was the unity of Hellenistic world, especially from a frontier viewpoint? How can we know and discuss the effects of the Hellenization process over non-Greek communities in that context? The harsh methodological challenges in the analysis of the highly

Heródoto, Unifesp, Guarulhos, v.4, n.1 - 2019.1. p. 122-138

DOI: 10.34024/herodoto.2019.v4.10091 
fragmented sources of Bactrian history before the French excavations defined by Holt as the 'ultimate test for History, Archaeology and Numismatics' (Holt, 1999: 9) - set the ground for racial, cultural, economic and political speculations produced according the models created by each author: the Bactrian documentary gaps forced them to express more clearly the limits and possibilities of his views on the Hellenistic world.

The paper begins with an overview of recent research on Hellenistic Bactria in order to make more visible the gaps Niebuhr had to deal. Then, we discuss how Niebuhr represented Hellenistic Bactria, relating it to the author' conceptions about the period as well as his political agendas. Finally, we summarize and conclude the paper by pointing directions for a fruitful dialogue between Hellenistic History and Global History, considering each historiographical background.

\section{Bactria in the recent Hellenistic History and Archaeology}

At the crossroad of the Iranian plateau, the Indus valley and the Central Asian steppes, Hellenistic Bactria, at the heart of Eurasia, was the stage of multiple cultural and economic exchanges between very different peoples: Persians, Iranians, Tajiks, Greeks, Indians and Yuezhis interacted in many different ways, from war to peace, from coexistence to submission. The evidence produced by recent research includes urban centers, dispersed settlements, inscriptions, coins, statues, pottery and buildings, which has supported constantly revised interpretations (Aldrovandi, 2010; Mairs, 2016). In a sense, Hellenistic Bactria is a laboratory of interdisciplinary work (from History and Archaeology to Numismatics and Art History) as well as for the discussion of some of the central issues of Global History.

The contemporary place of Hellenistic Bactria in Ancient History is, however, recent: the documentary gaps of Bactrian history, until the second half of the twentieth century, supported the double movement of extreme scholarly caution and free poetic imagination (Holt, 1999). This situation changed radically with the accidental discovery of the Hellenistic city of Aï Khanoum in the 1960's, in the contemporary frontier between Afghanistan and Tajikistan, on the Amu Daria valley, the ancient Oxus river (Martinez-Sève, 2015). Covering a triangular area of around 100 ha, the site of Aï Khanoum was at the center of Bactria, a former Achaemenid satrapy which, in Hellenistic times, became an independent kingdom ruled by Greek dynasties which ruled it until the late second century B.C. The site's importance, known from the nineteenth century, was fully recognized only after the beginning of the excavations conducted by the 
Délégation Archéologique Française en Afghanistan between 1964 and 1978, after the accidental discovery of Greek architectural elements by the Afghan king Muhammad Zaher Shah during a hunting in 1961.

The first volume of the series Fouilles d'A $\ddot{i}$ Khanoum appears in 1973; the ninth and more recent volume appeared in 2013. The detailed publication of the findings became particularly important after the sacks on the site and at the Kabul museum during the Afghan wars of the last decades. The campaigns revealed a city with many Greek-style buildings, such as propylaea, walls and fortifications, houses, sanctuaries, tombs, a gymnasium and the easternmost Greek theater. Besides the buildings, an impressive amount of pottery fragments, sculpture, jewelry, coins and inscriptions revealed details of city's culture, administration and relation with non-Greeks communities. Consider, for example, the famous Clearchus' inscription on a stone base, found in 1966 at the sanctuary of the city founder Kineas (Robert, 1968; Holt, 1999: 37-47; Verhasselt, forthcoming). The inscription says the one Clearchus - probably the Clearchus of Soli, an Aristotle's disciple - brought the Delphic maxims; the last maxim, inscribed over the base, reads: 'As a child, be well-behaved; in puberty, be self-restraint; in middle age, be righteous; as an old man, be well-advised; upon death, be without sorrow' (Verhasselt, forthcoming: 9). The inscription's text and location seem to reinforce the colony's Greek identity, referencing it to the Panhellenic sanctuary of Delphi, by Greek settlers surrounded by multiple non-Greek groups. In addition, the presence of diverse non-Greek elements in the city's landscape, especially in the temples with oriental-style façades and a palace with a peristyle open court, helped to direct scholars' attention to the interactions between Greek settlers and non-Greek locals.

Aï Khanoum is the most famous, but not the only well-documented site of Hellenistic Bactria. Another site is the sanctuary in Takht-i Sangin, near the Oxus river and probably dedicated to it, with Greek and oriental architecture elements on the plan and elevation; the votive deposits includes Greek-style statues, pottery, coins, ivory work and weapons (Litvinskiy; Pichikiyan, 1981).

The discoveries at Aï Khanoum and Takht-i Sangin, especially the stone inscriptions and coins, allowed a more precise reconstitutions of Bactrian political history in the third and second centuries B.C., such as those proposed by the numismatist Frank Holt. According to Holt (1999), after an earlier settlement in the time of Alexander, Seleucus I sent his son Antiochus as viceroy of the Bactrian satrapy in the early third century, in order to contain desertion of the first settlers. In Bactria, Antiochus developed the colonization process and created the first local mint. Under Heródoto, Unifesp, Guarulhos, v.4, n.1 - 2019.1. p. 122-138 
the Bactrian satrap Diodotos I, the region enjoyed peace and prosperity, especially in the period between c. 280 and 240; as a result, the satrap acquired a growing power and autonomy from the Seleucid court. In this process, a pivotal event was the expulsion of the nomad leader Arsaces, who have stablished himself in Bactria in the 250's B.C.; Arsaces then fled to the neighbor satrapy of Parthia, where he would create his own independent kingdom. Possibly connected to that event, a new coinage appeared with the portrait of Diodotos I, but still inscribed with the name of the Seleucid king. Diodotus II, his son, became satrap around 240 B.C., and soon declared himself independent king. Euthydemos, a local rival, rebelled against Diodotus II, who must have allied himself with Arsaces of Parthia; the conflict finished around 225 B.C. with the invasion of Aï Khanoum, the fall of Diodotus II and the establishment of the Euthydemid dynasty. The expedition of the Seleucid king Antiochus III to the empire's eastern frontier, in the late third century, did not destroyed the autonomy of Graeco-Bactrian kingdom, which, nonetheless, recognized the formal Seleucid suzerainty. The kingdom of Bactria maintained his independence until c. 150 B.C., when the nomad tribes Yuezhi, fleeing from the Chinese empire, invaded Bactria and Sogdiana, and created their own kingdom.

Under the Diodotids, according to Holt (1999), Bactria became much more than a corridor between Central Asia and the Mediterranean. The Bactrian coinages of the time, especially the bronze series, reveal varied dimensions of the economic and cultural integration of Greeks and non-Greeks. A telling example is the assimilation of the Greek goddess Artemis to the Iranian goddess Anahita: associated to the Moon, the wildlife and childbirth, Artemis/Anahita cohabited the Diodotid numismatic iconography with the dynastic god Zeus. Holt event suggests that Artemis/Anahita was the city goddess of Aï Khanoum, which means in modern Tajik language 'Lady Moon'. Additionally, Holt interprets the absence of the dog in Artemis/Anahita coins, a common feature of Artemis' numismatic iconography, as a caution the Diodotids had to not associate the goddess with the local cult practices related to dogs, which the Greeks abominated since the times of Alexander (Holt, 1999: 121-3).

The archaeological exploration of monumental sites such as Aï Khanoum and Takht-i Sangin, between the 1960 and 1980's, followed a method which valorized architecture, epigraphy and art: individual structures, inscriptions and aesthetic valued artifacts were narrowly described in the long reports of DAFA, with a clear preference for Greek monuments (Aldrovandi, 2010). However, between 1974 and 1978 archaeological surveys were conducted in the Oxus valley under the direction of JeanClaude Gardin, emphasizing previously neglected aspects such as pottery

Heródoto, Unifesp, Guarulhos, v.4, n.1 - 2019.1. p. 122-138

DOI: 10.34024/herodoto.2019.v4.10091 
distribution, irrigation systems and settlement patterns (Gentelle, 1989; Lyonnet, 1997; Gardin, 1998). The surveys, guided by the irrigation network, revealed a much broader landscape in time and space: the campaigns surveyed c. $200 \mathrm{~km} 2$ in the Dasht-i Qala plain, revealing 350 sites, and c. $1500 \mathrm{~km} 2$ in East Bactria, revealing 474 sites. The archaeologists proposed a chronology divided in five phases, from the Neolithic to the Islamic period. The Hellenistic period corresponds to the fourth phase; according to the archaeologists, rather than have represented a profound transformation in the irrigation system or the settlement pattern, the Hellenistic period expanded the existing networks according to growing patterns defined in the previous, Achaemenid period (Aldrovandi, 2010).

Thus, the East Bactria surveys, whose results were published between 1989 and 1998, altered deeply the region's research parameters. The impact of the Hellenization process was noticeably reduced: against a broader chronological and geographical framework, the creation of the Greek colony of Aï Khanoum and the nearly two centuries of Greek domination over the region, rather than radically change previous patterns, reinforced and expanded them. In this context, the very meaning of the Hellenization process must be reconsidered: no more an enclave of Hellenicity against the multitude of more or less Hellenized locals, the Graeco-Bactrian period should be interpreted as a part of the longer history of the local population's relation with foreign empires and cultures (Aldrovandi, 2010). The concept of Hellenization, in parallel to the analogous change in the concept of romanization as part of the Mediterranean History (Morales, 2014), would be embedded in the local, non-Greek histories. Thus, the paradigm of Achaemenid continuity in the Hellenistic period, formulated first by M. Rostovtzeff and recently championed by P. Briant (2015), then gained a new allied. Such shift, surely, apart the specific methodological dimensions (archaeological methods and source criticism), is linked to the diffusion of post- and decolonial perspectives in Humanities from the late twentieth century, which criticized the central role of European imperialistic experiences in the Hellenistic paradigms' formulation (Alcock, 1994; Aldrovandi, 2010).

This different framework has shed, also, new light on Aï Khanoum research itself, insofar as the former Hellenization process concept led the archaeologist to neglect non-Greek sites in the city's environs. The Achaemenid 'circular city' of Kohna Qala, circa $2 \mathrm{~km}$ far Aï Khanoum and the many non-Greek architectural and urbanistic elements in the city's urban fabric, for example, are indicators of an Achaemenid previous history of the site (Aldrovandi, 2010; Mairs, 2014). 
The research on monumental sites such as Aï Khanoum and Takht-i Sangin, on the one hand, and on spatial patterns of Bactrian territorial occupation in the longue durée, on the other, have opened new possibilities for the discussion of methodological and morphological issues both of Bactrian and Hellenistic History and Archaeology in general. Hellenistic Bactria, in the twentieth century disputed by Greek and Indian History (Holt, 1999: 12), nowadays seems to assume his place in the long-term history of Eurasian societies and macroregions' interaction.

This shift, also, dialogues with well-established academic patterns linked with the Hellenization process paradigm such as formulated in the nineteenth century. The many and varied monographs on defined source corpora and the regional syntheses, subjected to a close scrutiny by specialized literature, simultaneously influenced and were influenced by broader historiographical models built upon the quest for the meaning of the Hellenistic period. Here, we discuss the solutions adopted by $\mathrm{B}$. Niebuhr in his macronarrative produced in the 1820's, which set the ground for later discussions, in particular the one proposed by Droysen, whose inversion of Niebuhr's model will be discussed in another paper.

\section{Niebuhr's Hellenistic Bactria: decadence, race and empire}

Born in 1776 in Copenhagen, Barthold Niebuhr was son of the famous Danish explorer Carstein Niebuhr, whose researches on Iran assured him a special place in the history of cuneiform decipherment. Raised in seclusion in a housed full of History, Geography and Philology books aside the nascent European press, B. Niebuhr started studies in Law and Philosophy at the University of Kiel in 1794, when, according his letters, he was already sure about his plans to pursue a career as philologist. After work in the Danish bureaucracy and to travel for England and Scotland, in 1810 he became professor of Roman History at the recently founded Berlin University, post he would leave in 1813 to fight in the Prussian antiNapoleonic liberation war. The year at Berlin University, whose first dean was the philosopher and anti-Napoleonic radical activist J. G. Fichte, led Niebuhr to engage in the debate on the relations between Law History and Philosophy, whose extremes were represented by his colleagues F. de Savigny and W. Hegel. The importance of this debate could hardly be underestimated: it was in question both the relation between Prussian and the several law systems of Germanic communities and the very modern concept of History (Iggers, 2012: 66). Niebuhr's contribution, on behalf History's particularism and source-guided research, was the historical method of source criticism, applied by him mainly on Livy as source for

Heródoto, Unifesp, Guarulhos, v.4, n.1 - 2019.1. p. 122-138

DOI: 10.34024/herodoto.2019.v4.10091 
the history of Roman Law. The discovery of the ager publicus is one of the most influent accomplishments, directly linked with the problem of the private property's nature and origin (Momigliano, 1982). The research results were published in Niebuhr's History of Rome already in 1811, soon bringing fame to the author and his method.

After a long period of public service in Prussian diplomacy, Niebuhr resumed his university career only in 1823, becoming professor of Ancient History at the Bonn University - post he would occupy until his death in 1831. His first course was dedicated to 'die Spätere Griechisch Geschichte im Allgemeinen', i.e., the period between the fourth century B.C. and the Roman conquest; later, he gave lectures on the classical and pre-classical periods of Ancient History, besides courses on Ancient geography and ethnography. The lectures' notes, his and of his students, were posthumously published as the Vörtrage über alte Geschichte, whose third volume comprised the lectures on the 'Later General Greek History'. In the first volume's opening lesson, Niebuhr explains his morphological choices: Antiquity would be divided in Ancient History and Roman History, the first one being centered on the Greeks and his contacts. This division was based upon the use of Pompeius Trogus' and Livy' works as guides (Niebuhr, 1852a: 33-45). While Livy structured his narrative centering it on Rome's history, Pompeius Trogus (summarized by Justin) did it on Greece's history. The two strategies informed Niebuhr's division, the Later Greek History being the final period of Ancient History before incorporation in Roman History.

In other work, we have discussed with more detail Niebuhr's morphological and methodological choices (Morales, 2019); here, we will concentrate on the representation of Bactria in the Lectures. It is worth to note, however, that Niebuhr did not abandoned the narrative trope of Greek moral decadence after the Macedonian conquest (Briant, 2005; Payen, 2005). Despotic and ruthless as the contemporary Ottoman turks, Niebuhr's Macedonians built an empire over the Greek cities by suffocating their freedom. Demosthenes, for his opposition to Philip, is praised as the last defender of liberty, beaten by the epochal decadence which replaced Assemblies and Councils' debates by Courts' intrigues in the explanation of political history (Niebuhr, 1852c: 41-46). Besides Ottoman Empire, Ancient Macedonia is also compared to Napoleonic France: the lost freedom of Greek cities was parallel to that of Prussia under foreign rule (Niebuhr, 1852c: 54).

The moaning tone of the decadence trope didn't prevent Niebuhr to offer extremely rich and varied analyses and narratives: political and military history is intersected with reflections on moral, art, economy, geography Heródoto, Unifesp, Guarulhos, v.4, n.1 - 2019.1. p. 122-138 
etc, based on all available literary, architectural and numismatic sources. However, when dealt with the eastern frontier of Macedonian domains, Niebuhr invariably centered his discussion on the problem of imperial unity and the limits of hellenization of 'Asian' communities.

The problem of imperial unity appears already in the first mention on Bactria, made in the second volume, dedicated to the classical period. According to Niebuhr, contrary to the fifth century, 'when India, on the Indus valley, was under Persian rule, and Bactria was one of the major provinces', in the times of Alexander 'Bactria was so weakly connected to empire that its satraps could easily become independent, and even India was lost' (Niebuhr, 1852b: 233). The opposition between imperial unity and satrapal independence, so, was an Achaemenid heritage.

In the third volume of the Lectures is plenty of mentions to Bactria, mainly when the author discussed the Seleucid empire. Niebuhr's major sources were, then, Polybius, Strabo, Pompeius Trogus [Justin] and Appian. The first mention appears on a discussion on the nature of Antiochus I's power. Although at first sight Antiochus I have extended his father's domains, Niebuhr says, the nature of imperial power was radically different: many parts of the empire, 'which his father had left him in a state of submission, asserted their independence', such as Cappadocia, Pontus, Armenia and Bactria, which 'became independent under a Macedonian king'. In that scenario, Antiochus I 'was obliged to be satisfied with maintaining a nominal supremacy in those parts' (Niebuhr, 1852c: 283). This state of affairs, nonetheless, assured the permanence of Greek institutions, unlike the case of the Indian states 'which having separated from the empire, returned to their own national institutions' (Niebuhr, 2852c: 283).

The tension between political independence and nominal supremacy would continue until Antiochus III, considered by Niebuhr 'not a great man', although 'his courtiers, not without reason, gave him the surname of the Great, because he restored the empire', finishing the 'state of ferment and disorganization' of Upper Asia (Niebuhr, 1852c: 298). However, the fragility of imperial unity has not disappeared: Niebuhr compares Antiochus III's authority over Asia to that of the Ottoman Empire, saying that 'in distant countries, as, e.g., at Bactria, the authority of the Syrian kings was as little respected as that of the Sultan is at Bagdad or in Egypt' (Niebuhr, 1852c: 346).

The Seleucid empire's major enemy were his satraps; nominal supremacy resembled only remotely a united empire. The vectors of division were, ironically, the cities founded by Alexander and the Seleucids to reinforce the empire's unity. Niebuhr's explanation was based on demographic and

Heródoto, Unifesp, Guarulhos, v.4, n.1 - 2019.1. p. 122-138

DOI: 10.34024/herodoto.2019.v4.10091 
racial reasoning: the Greek-Macedonian cities, instead of promoting the Hellenization of the Asian peoples, were inversely Asianized by them. It is worth quoting the complete passage:

\begin{abstract}
Although those towns were situated in the midst of barbarous countries, still they had their Greek institutions. They were real republics with their phylai and Boulé, etc., and such republican towns existed not only on the coast of the Mediterranean, but even very far in the interior of Asia. The number of their inhabitants was very small compared with that of the surrounding Asiatics, and yet the numbers of Greek and Macedonian soldiers flocking to those towns, had so much drained Europe, that Greece and Macedonia were in a state of desolation in consequence. Through intermarriage with Asiatic women, there arose a mixed race, like that of the half caste in India, and the Pullans at the time of the crusades. Such a mixed race always has a peculiar character: the Indian half caste, the Mulattoes, and others, even if they were not distinguished by their colour, might very easily be recognized by their character. They are active, lively, and stirring, but they generally cannot be trusted at all on account of their Asiatic education. As children they are pretty, intelligent, and learn easily, but do not advance beyond mediocrity; they nowhere appear superior to, or more respectable than the natives. Such towns, with a degenerate Greek language and the forms of a republic, which often had no real existence, were the resorts not only of Greeks and Macedonians, but in a great measure of Asiatics also, and continued to exist even as late as the time of the Sassanidae, that is, five hundred years after. [...] Those towns were intended to serve as strong points, to secure to some extent the submission of the provinces; but they were, on the contrary, the cause of insurrections in which the provinces were torn from the empire. But what were called Greeks, that is, the Macedonians and Greeks, were not so purely Greek in Asia as they were at Alexandria, where, in consequence of direct communication by sea, Greek was spoken in much greater purity (Niebuhr, 1852c: 298-301).
\end{abstract}

The demographic argument, by which the Greek migration was insufficient to face the Asiatic majority, is at the basis of the racial consequence: the mixed marriages generated a mixed race, composed by deceitful, non-pure Greek citizens, who corrupted the Greek institutions which remained only formally. The oriental 'Greek' cities, rather than ensure empire's unity, led to insubordination. The inferior Asiatic nature is reiterated when Niebuhr evaluates Antiochus III's 'greatness': despite being victorious 'as far as the frontier of Bactria', he was beaten by Rome. Thus, 'if he had not undertaken the war against the Romans, his reign would be very illustrious in history; but his power was great only against Asiatics' (Niebuhr, 1852c: 347).

Nonetheless, Niebuhr recognizes the role the Greek cities had in the diffusion of Greek culture. After stressing the influence of the Greek culture over the Sassanians, Niebuhr mentions Bactria in the debate over the resemblances between Greek and Indian philosophies. Reasserting the refuse to the 'Indian origin of Greek philosophy' hypothesis, Niebuhr 
suggests that one 'cannot account for the resemblance [between them], except by tracing it to the connection of the Indians with the GraecoMacedonian kings at Bactria' (Niebuhr, 1852c: 300). However, the presence of the Greek culture in the East would remain limited to its influence over succeeding cultures, such as those of Parthians and Indians - even Bactria would lose its Hellenicity. Independent from the Seleucid Empire, the Graeco-Macedonian kingdom of Bactria, together with the satrapies of Babylonia, Hircania and Media, would be incorporated to the Arsacid Empire, when, for Niebuhr, 'Asia again became completely Asiatic' (Niebuhr, 1852c: 466).

In sum, the historiographical representation of Hellenistic Bactria in Niebuhr's Lectures - a distant kingdom populated by a mixed race, with only partial adherence to Greek culture and to Seleucid empire, which would influence other cultures but would be unable to sustain the region's Hellenicity - served to discuss broader topics, such as the relation between cultural and political unity, and the risks of racial mixing. In the context of the Greeks' moral decadence, political unity depended on racial unity; the absence of the former, in the long term, meant submission to a non-Greek power and the vanishing of the Greek culture in Upper Asia.

Given the parallel Niebuhr trace between 'Late Greece' and early nineteenth century Prussia, it seems not to be an exaggeration to associate his representation of Bactria to the intense debates, held at the universities, on the racial, juridical and military formation of the German national state led by the Prussian kingdom (Breuilly, 2007, 2008). On the one hand, the ambiguity between the moaning on the Greek cities' lost freedom under Macedonian rule (itself associated to Ottoman and Napoleonic rule), and, on the other, the critique to the Seleucid failure to maintain the empire (opposed to Rome), maybe reflects an ambiguous posture Niebuhr had in relation to the still under construction Prussian unification project in the 1820 's. The parallel between Napoleon and Philip II of Macedonia, in particular, composed the rhetoric of the Germanic rebirth against French occupation, using Demosthenes as a symbol (Canfora, 2007). In any case, the very nature of the work - lecture notes - asks for caution in a search for an absolutely coherent logical system: the parallels the professor Niebuhr made in his lectures were all but systematic, appearing here and there according his teaching choices. 


\section{Conclusion}

The history and archaeology of Hellenistic Bactria, deeply changed by the last decades' new discoveries, has for long attracted the scholars' attention: the exiguous and fragmented sources available before the 1960's excavations obliged historians to expose more clearly the strengths and weaknesses of their models used to build coherent syntheses. In this paper, we have discussed one of the earlier synthesis of the period later defined as 'Hellenistic'. By doing this, we were able to observe how general models were adapted to explain a limit situation in both geographical and methodological perspectives. Niebuhr's model represented Bactria as an Asianized Macedonian kingdom, a product of the general decadence of the period: the Macedonian cruelty, engaged with the treacherous Asian nature, led to secession against the Seleucid rule. Nevertheless, however unable to retain Greek culture, the Bactrian kingdom left a cultural legacy by influencing other cultures and religions, such as Buddhism.

Niebuhr's historiographical representation of Bactria, however dependent upon his methodological choices in a context of source scarcity, dialogues deeply with his experience of European political and social transformations in the early nineteenth century. Witness of the Prussian defeat and later victory over Napoleonic France, the diplomat and professor Niebuhr participated in the reconstruction of Prussian state with a central role in the building of modern German historical science; however, the Prussian unification project of the German-speaking polities, though on the horizon, was much less influent to his view of the Hellenistic period than the Napoleonic oppression experience. The parallel between Prussia and Athens, on the one hand, and Macedonia and France and the Ottoman Empire, on the other, strengthened by the praise of Demosthenes' fight against Philip II of Macedon, demonstrate the decadence paradigm's relevance to the comprehension both of Ancient Greek and Modern Prussian history.

Surely, the interaction between contemporary agendas and historiographical interpretation are not unique to nineteenth century scholars: the new Bactrian histories and archaeologies are as well related to deep cultural and political changes. On the one hand, the criticism of Hellenocentrism in the region's history is linked to the diffusion of postand decolonial approaches, derived from the collapse of European empires in Africa and Asia in the middle of the twentieth century; on the other hand, the renewed importance of studies on interethnic interactions in Central Asia answers to the emergence of Global studies and the globalization process itself, especially facing the rise of Chinese hegemony. In any case, the concern with the depth of the Hellenization process was, 
as we have seen, already present in one of the earlier modern formulations of Ancient History. In this sense, the radical change in the available sources, made by the French excavations, only partially altered the issues and questions to be discussed. In fact, the agendas of contemporary Global and decolonial scholarship functions as an inverted mirror of the nationalist, Eurocentric and racist interpretations which fueled the foundation of the modern historical science. It is not the case, surely, to abandon the debates bequeathed by the past in the name of a total refoundation: their renewed relevance is a symptom of historical structural continuities of modern world, such as imperialism, capitalism and Globalscale integration. Rather, to discuss its historicity should encourage both historiographic self-criticism and the perception of the complexity of historical reality, irreducible to the anxieties about the formation and occasional collapse of Western Global hegemony throughout the last two centuries.

\section{Bibliography}

ALCOCK, Susan E. Breaking up the Hellenistic world: survey and society. In: MORRIS, IAN (Org.). Classical Greece: ancient histories and modern archaeologies. Cambridge [England]; New York, NY, USA: Cambridge University Press, 1994. p. 171-190.

ALDROVANDI, Cibele Elisa Viegas. A morfogênese espacial da antiga Báctria: interações e paradigmas em uma paisagem fractal. Revista do Museu de Arqueologia e Etnologia, n. 20, p. 163, 9 dez. 2010.

ARRIGHI, Giovanni. O longo século XX: dinheiro, poder e as origens de nosso tempo. Tradução Vera Ribeiro. Rio de Janeiro; São Paulo: Contraponto Ed. UNESP., 2006.

BREUILLY, John. Nationalism, Power and Modernity in Nineteenth - Century Germany. London: German Historical Institute, 2007.

BREUILLY, John. The Formation of the First German Nation-State, 1800-1871. Houndmills: Palgrave, 2008.

BRIANT, Pierre. Alexandre et "hellénisation de l'Asie;. L'histoire au passé et au présent. Studi Ellenistici, v. 16, p. 9-69, 2005.

BRIANT, Pierre. Michael Rostovtzeff, Elias Bickerman and the "Hellenization of Asia": from Alexander the Great to WWII. Writing 
History in Time of War Michael Rostovtzeff, Elias Bickerman and the "Hellenization of Asia". Stuttgart: Franz Steiner Verlag, 2015.

CANFORA, Luciano. Johann Gustav Droysen, Histoire de l'Hellénisme. Anabases. Traditions et réceptions de l'Antiquité, n. 5, p. 277-280, 1 mar. 2007.

DROYSEN, Johann Gustav. Histoire de l'hellénisme, vol. 1. Tradução Auguste Bouché-Leclercq. Paris: E. Leroux, 1883a.

DROYSEN, Johann Gustav. Histoire de l'hellénisme. vol. 2. Tradução Auguste Bouché-Leclercq. Paris: E. Leroux, 1883b.

DROYSEN, Johann Gustav. Histoire de l'hellénisme. vol. 2. Tradução Auguste Bouché-Leclercq. Paris: E. Leroux, 1883c.

GARDIN, Jean-Claude. Prospections archéologiques en Bactriane orientale (1974-1978). vol. 3, Description des sites et notes de synthèse. Paris: Ed. Recherche sur les civilisations, 1998.

GENTELLE, Pierre (1933-2010) Auteur Du texte. Prospections archéologiques en Bactriane orientale (1974-1978). vol. 1, Données paléogéographiques et fondements de l'irrigation: / par Pierre Gentelle; avec des contributions de Carmine Marinucci, Fabienne O. Vallino et Jean Trichet; cartogr. de Madeleine Sintes-Aioutz... Paris: De Boccard, 1989.

GUARINELLO, Norberto Luiz. Uma Morfologia da História: As Formas da História Antiga. Politeia: História e Sociedade, v. 3, n. 1, 2003.

HOLT, Frank Lee. Thundering Zeus: the making of Hellenistic Bactria. Berkeley: University of California Press, 1999.

IGGERS, Georg G. The German Conception of History: The National Tradition of Historical Thought from Herder to the Present. [S.1.]: Wesleyan University Press, 2012.

KNUST, José Ernesto Moura. Os Pláucios, a emancipação da plebe e a expansão romana: conectando as histórias interna e externa da República Romana. Esboços: histórias em contextos globais, v. 26, n. 42, p. 234-254, 16 jul. 2019.

LITVINSKIY, B. A.; PICHIKIYAN, I. R. The Temple of the Oxus. Journal of the Royal Asiatic Society of Great Britain and Ireland, n. 2, p. 133-167, 1981.

LYONNET, Bertille. Prospections archéologiques en Bactriane orientale. 2, Céramique et peuplement du chalcolithique à la conquête arabe: 1974-1978. Paris: De Boccard, 1997. 
MAIRS, Rachel. Achaemenid Ai Khanoum. Archäologische Mitteilungen aus Iran und Turan, v. 46, 2014.

MAIRS, Rachel. The Hellenistic Far East: Archæology, Language, and Identity in Greek Central Asia. Berkeley: University of California Press, 2016.

MARTINEZ-SÈVE, Laurianne. Ai Khanoum and Greek Domination in Central Asia. ELECTRUM, v. 2015, n. Volume 22, p. 17-46, 22 dez. 2015.

MOMIGLIANO, Arnaldo. Niebuhr and the Agrarian Problems of Rome. History and Theory, v. 21, p. 3-15, 1982.

MORALES, Fabio Augusto. Graecia capta, novamente: considerações sobre os limites da nova romanização da Grécia. Revista do Museu de Arqueologia e Etnologia., v. Supp. 18, p. 91-97, 2014.

MORALES, Fabio Augusto. Niebuhr e a História Antiga no século XIX: experimentações morfológicas. No prelo. 2019.

MORALES, Fábio Augusto; PEREIRA, Mateus Henrique de Faria. O convite da história global. Esboços: histórias em contextos globais, v. 26, n. 41, p. 7-13, 30 jan. 2019.

MORALES, Fábio Augusto; SILVA, Uiran Gebara Da. História Antiga e História Global: afluentes e confluências. No prelo., 2019.

NIEBUHR, Barthold Georg. Lectures on ancient history, from the earliest times to the taking of Alexandria by Octavianus. Comprising the history of the Asiatic nations, the Egyptians, Greeks, Macedonians and Carthaginians, vol. 1. Tradução Leonhard Schmitz. Philadelphia: Philadelphia, Blanchard, 1852a.

NIEBUHR, Barthold Georg. Lectures on ancient history, from the earliest times to the taking of Alexandria by Octavianus. Comprising the history of the Asiatic nations, the Egyptians, Greeks, Macedonians and Carthaginians, vol. 2. Tradução Leonhard Schmitz. London: Taylor, Walton, Maberly, 1852b.

NIEBUHR, Barthold Georg. Lectures on ancient history, from the earliest times to the taking of Alexandria by Octavianus. Comprising the history of the Asiatic nations, the Egyptians, Greeks, Macedonians and Carthaginians, vol 3. Tradução Leonhard Schmitz. London: Taylor, Walton, Maberly, 1852c.

PAYEN, Pascal. Johann Gustav Droysen et l'histoire de l'hellénisme. L'époque hellénistique entre Alexandre et la Prusse. In: DROYSEN, GUSTAV. Histoire de l'hellénisme: 2 volumes. Tradução Auguste BouchéLeclercq. Éd. intégrale ed. Grenoble: Editions Jérôme Millon, 2005.

Heródoto, Unifesp, Guarulhos, v.4, n.1 - 2019.1. p. 122-138

DOI: 10.34024/herodoto.2019.v4.10091 
ROBERT, Louis. De Delphes à l'Oxus, inscriptions grecques nouvelles de la Bactriane. Comptes rendus des séances de l'Académie des Inscriptions et BellesLettres, v. 112, n. 3, p. 416-457, 1968.

SCOPACASA, Rafael. Hegemonia romana e transformações culturais no mediterrâneo (séculos IV-II a. C.): novas perspectivas da história global. Revista de História, n. 177, p. 01-35, 23 maio 2018.

SEBASTIANI, Breno Battistin. Droysen's concept of Hellenism between philology and history. Aitia. Regards sur la culture hellénistique au XXIe siècle, n. 5, 8 jul. 2015.

SILVEIRA, Aline Dias Da. Algumas experiências, perspectivas e desafios da Medievalística no Brasil frente às demandas atuais. Revista Brasileira de História, v. 36, n. 72, p. 39-59, 15 set. 2016.

THONEMANN, Peter. The Hellenistic age. First edition ed. Oxford, United Kingdom: Oxford University Press, 2016. 